\title{
Alpha-Hemolytic Streptococcus
}

National Cancer Institute

\section{Source}

National Cancer Institute. Alpha-Hemolytic Streptococcus. NCI Thesaurus. Code C86141.

A bacterium that is assigned to the genus Streptococcus that is able to reduce the iron content in hemog lobin in red blood cells, thus producing green colored colonies on blood agar plates. 